\title{
FEASIBILITY INDICATORS OF STUDY BOOKS USED ELEMENTARY SCHOOL STUDENTS
}

\section{Bayu Purbha Sakti}

Universitas Widya Dharma Klaten

bayups@unwidha.id

\section{Article History}

accepted 09/07/2018

approved 01/08/2018

published 17/09/2018

\section{Keywords}

zoning system, elementary school student, elementary school book, elementary school teacher

\begin{abstract}
Suicide primary school girls, 2 reporting discourses, and zoning system require that each elementary school has books that attract students and teachers to read them. Negative content and typing errors written in the book will cause different understandings experienced by elementary school students. Elementary school student who have good linguistic intelligence will be easy to memorize and have extensive vocabulary. Elementary school student with high visual-spatial intelligence will be active in the imagination. Books used by primary schools must meet the values and norms applicable in the community. Primary schools are required to evaluate all the books used in primary schools. Sanctions are granted to authors and publishers if any incorrect information is written in the book. Primary school students will think positively or negatively by looking at textbooks. Eligibility of elementary school textbooks is the responsibility of many parties in the field of education even though teachers are an important component that should assess the appropriateness of textbooks.
\end{abstract}

Social, Humanities, and Education Studies (SHEs): Conference Series https://jurnal.uns.ac.id/shes 


\section{PENDAHULUAN}

Seorang anak putri yang bersekolah di sekolah dasar pada kelas 4 nekat mengakhiri hidup karena nilai hasil ujiannya buruk (Vinanda, 2017). Kasus tersebut diberitakan terjadi di Kota Xuzhou di Provinsi Jiangsu Negara China. Anak tersebut mendapatkan hasil nilai buruk di ujian semesternya. Gurunya juga melarang anak tersebut untuk mengikuti ujian selanjutnya. Hal ini dikarenakan anak tersebut dianggap akan membuat nilai rata-rata dalam satu kelas akan mengalami penurunan. Masalah ini seharusnya tidak dilakukan guru karena setiap siswa sekolah dasar (SD) berhak mendapatkan pendidikan yang layak dari perlakuan guru, teman, dan segala aspek dalam bidang pendidikan.

Hasil buruk nilai ujian yang didapati siswa dalam ujian termasuk hasil kemampuan akademik. Siswa yang belajar di sekolah dasar tidak hanya dinilai dari kemampuan akademiknya tetapi seharusnya siswa juga dinilai dari segala aspek kemampuan perkembangannya. Perkembangan emosi dan mental siswa adalah beberapa perkembangan yang menjadi masalah untuk dinilai di dalam rapor perkembangan.

Adanya wacana 2 rapor tentu saja menjadi permasalahan bagi guru. Guru dituntut bekerja bisa menghasilkan rapor kemampuan akademik dan perkembangan siswa. Oleh karena itu, guru harus membutuhkan buku pelajaran atau buku lainnya sebagai pedoman atau petunjuk untuk menilainya.

Dua jenis rapor diwacanakan Muhadjir Effendy supaya dijalankan siswa dalam rangka menyukseskan pendidikan karakter dengan masa 12 tahun wajib belajar (Bomantama, 2018). Dua jenis rapor itu dibuat untuk mempermudah sekolah dalam menilai perkembangan karakter siswa. Penilaian perkembangan karakter dibuat supaya penilaian yang ditujukan ke siswa melengkapi penilaian akademik. Penilaian karakter dilaksanakan setiap saat guru menempati kelas atau sekolah (Sakti, 2017a).

Perkembangan siswa sekolah dasar ditentukan salah satunya oleh jarak siswa bersekolah. Sistem zonasi yang digunakan sekarang diwacanakan akan mempermudah guru dalam menilai perkembangan siswa sekolah dasar. Siswa sekolah dasar yang memiliki jarak jauh dengan sekolahnya akan memiliki masalah mengenai persiapan kemampuan akademiknya.

Sekolah dasar yang didirkan pada sebuah zonasi berarti berada dalam satu kecamatan dan tidak bisa didirikan di luar kecamatan. Sistem zonasi mengutamakan kuota 70 persen bagi siswa yang ingin mendaftar sekolah dasar (Media, 2018). Pendaftaran Peserta Didik Baru (PPDB) yang diselenggarakan secara teknis di Kota batam menggunakan sistem zonasi. Kuota siswa yang mendaftar sekolah dasar sebesar 15 persen dimiliki siswa di dekat sekolah, siswa miskin mendapat kuota sebanyak 10 persen, dan sisa 5 persen dimiliki siswa di luar Batam.

Sistem zonasi yang diterapkan pemerintah daerah akan menimbulkan masalah bagi siswa yang ingin bersekolah favorit di kecamatan sebelahnya. Siswa tersebut sebenarnya dapat bersekolah favorit dengan menempuh jarak yang begitu dekat. Namun sekolah favoritnya berada berbeda kecamatan. Sekolah favorit tentunya memiliki koleksi buku-buku bagus di dalam perpustakaannya. Gambar-gambar menarik yang digambarkan di dalam buku akan mempermudah siswa sekolah dasar untuk membaca dan memahaminya. 
Buku yang menarik siswa sekolah dasar akan menjadi masalah jika konten yang ditulis di dalam buku meresahkan. Kasus buku-buku yang berjudul 'Misteri Hantu Gentayangan' dan 'Hantu Pojok Rumah' yang dikoleksi perpustakaan salah satu sekolah dasar telah meresahkan wakil rakyat. Wakil Rakyat atau Dewan Perwakilan Rakyat Daerah (DPRD) Kabupaten Malang meminta buku mengisahkan hantu ditarik (Aminudin, 2017). Mereka meminta agar buku-buku itu ditarik dan tidak dipinjamkan kepada siswa sekolah dasar yang menerimanya. Hal itu dilakukan supaya generasi muda tidak teringat akan kisah seram.

Kasus buku yang meresahkan juga didapatkan dari konten buku pelajaran sekolah dasar. Konten buku IImu Pengetahuan Sosial Kelas 4 sekolah dasar Kurikulum 2006 dikoreksi dan dibetulkan Kementrian Pendidikan dan Kebudayaan (Seftiawan, 2017). Konten yang dikoreksi dan dibetulkan pihak Kementrian Pendidikan dan Kebudayaan (Kemendikbud) adalah penulisan ibu kota Negara Israel yaitu Yerusalem. Revisi yang dilakukan tersebut bermula dari keresahan masyarakat karena ibu kota Negara Palestina adalah Yerusalem.

Revisi terhadap buku pelajaran sekolah dasar harus dilakukan supaya tidak menimbulkan masalah. Buku pelajaran sekolah dasar yang digunakan juga harus sesuai penilaian dari pihak kementerian. Buku Pendidikan Agama Islam sekolah dasar yang dinilai harus sesuai Keputusan Menteri Agama Nomor 437 tentang pentashihan buku-buku yang memuat tulisan ayat Al quran (Yulianto, 2017). Buku-buku agama yang dibaca siswa sekolah dasar sebaiknya mengandung konten yang disesuaikan perkembangan siswa tingkat sekolah dasar. Buku-buku agama harus mengandung ayat-ayat Al quran yang bisa dipahami siswa di tingkat sekolah dasar.

Anise Baswedan menjelaskan mengenai buku pelajaran yang digunakan di sekolah harus sesuai Peraturan Menteri Pendidikan dan Kebudayaan tentang buku yang diundangkan tahun 2016 (Bona, 2016). Penulis mencantumkan identitasnya secara lengkap yang dijadikan pertanggungjawaban mengenai isi buku. Kelengkapan identitas penulis akan mempengaruhi identitas bahwa buku itu layak atau tidak untuk digunakan di sekolah. Buku pelajaran sekolah dasar akan menentukan pola pikir siswa sekolah dasar. Konten materi yang ditulis dan digambar di dalam buku pelajaran akan mudah diingat siswa sekolah dasar. Oleh karena itu, permasalahan indikator kelayakan buku pelajaran yang digunakan siswa sekolah dasar harus diketahui khususnya oleh guru sekolah dasar.

\section{PEMBAHASAN}

Ada beberapa hal yang perlu dibahas untuk menjawab permasalahan indikator kelayakan buku pelajaran yang digunakan siswa sekolah dasar. Permasalahan tersebut dijawab dengan membahas perkembangan kecerdasan linguistik siswa sekolah dasar, perkembangan kecerdasan visual siswa sekolah dasar, pengawasan konten negatif dalam buku, dan pengawasan buku sekolah dasar.

\section{Perkembangan Kecerdasan Linguistik Siswa Sekolah Dasar}

Menurut Rohman (2011: 137), kecerdasan linguistik adalah kemampuan akal peserta didik untuk menggunakan kata-kata secara efektif, baik secara lisan maupun dalam bentuk tulisan. Menurut Suyadi (2010: 151), kecerdasan 
linguistik adalah kemampuan untuk menyusun pikiran dengan jelas dan mampu menggunakan secara kompeten melalui kata-kata, seperti bicara, membaca dan menulis.

Human rely heavily upon a person' skill in defining words dan upon language, in finding connections (and differences) among verbal concepts, and in knowing facts about the world (Gardner, 2011). Manusia menurut Gardner sangat bergantung pada keterampilan seseorang dalam mendefinisikan kata-kata dan pada bahasa, dalam menemukan koneksi (dan perbedaan) di antara konsep-konsep verbal dan mengetahui fakta tentang dunia.

Kecerdasan linguistik berkembang pada usia sekolah yaitu $6-14$ tahun. Anak usia sekolah dasar bisa mengembangkan kemampuan berbahasa dengan meningkatkan kompetensi bahasa (Sefrina, 2013:20). Kecerdasan yang dimiliki seorang anak akan menjadikannya bersemangat membaca buku, menulis karangan, meyimak dengan baik, dan dapat berbicara di depan umum dengan baik (Jasmine, 2012: 7). Siswa yang memiliki kecerdasan linguistik yang baik akan mempunyai ketrampilan menulis secara kreatif, mengarang cerita, mudah menghafal nama, tempat, tanggal, hal-hal kecil, mengeja kata-kata, dan memiliki kosakata yang luas (Armstrong, 2005: 25).

\section{Perkembangan Kecerdasan Visual Siswa Sekolah Dasar}

Kecerdasan visual spasial ialah kemampuan untuk melihat gambaran visual yang terdapat di sekitar secara tepat dan memperhatikan bagian atau rincian yang lebih kecil (Lwin, 2008: 73). Anak yang memiliki kecerdasan visual spasial akan memiliki kepekaan terhadap garis, bentuk, warna, ruang, bayangan, keseimbangan, harmoni, hubungan, dan pola yang bertumpu pada ketelitian pengamatan dan ketajaman penglihatan (Armstrong, 2005: 44).

Child understands that a material can be changed in shape without the mass being thereby affected, that objects still remain the same quantity and can be arranged, that a scene still contain the same elements and can be viewed from a different perspective (Gardner, 2011). Menurut Gardner, anak memahami bahwa suatu material dapat diubah dalam bentuk tanpa massa yang terpengaruh, bahwa benda-benda tetap memiliki kuantitas yang sama dan dapat disusun kembali, bahwa suatu pemandangan masih mengandung unsur-unsur yang sama dan dapat dilihat dari perspektif yang berbeda.

Peserta didik/ siswa dengan kecerdasan visual-spasial yang tinggi sungguh aktif dalam berimajinasi dan juga dapat mengungkapkan gagasannya dalam grafik yang lebih jelas dan ringkas (Suparno, 2004). Anak akan menjadi tertarik membaca jika gambar yang disajikan dalam suatu cerita mempunyai fungsi sebagai ilustrasi disesuaikan dengan materi dan ditambah pemberian warna (Ridha, Pradana, \& Mayarestya, 2017). Anak yang mempunyai kecerdasan visual spasial dapat membayangkan sesuatu dengan imajinatif da detil, anak senang membuat konstruksi 3 dimensi dari permainan seperti brick, balok, bombiq, dan lego serta anak juga belajar mengamati bentuk, benda, dan warna (Musfiroh, 2008). Anak yang menggambar sesuatu mendekati aslinya atau persis adalah ciri anak tersebut mempunyai kecerdasan visual yang baik (Sumiati, 2014). 


\section{Pengawasan Konten Negatif Dalam Buku}

Pengawasan konten negatif yang dicetak di dalam buku menjadi tanggung jawab seorang guru. Guru sekolah dasar mempunyai tanggung jawab tidak hanya mengajar tetapi mendidik dan berperan sebagai pembimbing yang memberikan pengarahan serta menuntun siswa dalam belajar (Sakti, 2016a). Anak usia sekolah dasar ditangani guru sekolah dasar karena guru sekolah dasar mempunyai keahlian dan fungsi dalam penanganan tersebut (Sakti, 2017b).

Siswa sekolah dasar diharapkan menjadi orang yang berjiwa positif dan menjaga perdamaian. Setiap orang memelihara kondisi damai dalam masyarakat (Yudhoyono, 2012). Siswa sekolah dasar mempunyai kewajiban sebagai Warga Negara Indonesia dalam memelihara perdamaian dengan:

a. Mengembangkan toleransi dan menghormati dalam menjalankan ibadah agama.

b. Menghormati perbedaan bahasa, suku, dan ada istiadat.

c. Memperlakukan manusia sesuai harkat dan martabat.

d. Mengakui manusia dalam persamaan hak dan kewajiban tanpa membedakan suku, agama, ras, kedudukan sosial, warna kulit, keturunan, kepercayaan, dan jenis kelamin.

e. Mengembangkan persatuan Indonesia dengan dasar kebhineka-tunggalikaan.

Anise Baswedan menjelaskan bahwa pihak sekolah harus memenuhi nilai dan norma positif yang ada di masyarakat dalam menggunakan buku tidak mengandung unsur kekerasan, pornografi, paham radikalisme, serta tidak terdapat nilai penyimpangan lainnya (Bona, 2016). Edukasi anti radikalisme dan terorisme dilakukan kepada semua elemen masyarakat di daerah dan pengembangan kreativitasnya dari berbagai perspektif (Alius, 2017).

Pornografi ialah sketsa, gambar, ilustrasi, foto, suara, bunyi, tulisan, animasi, kartun, percakapan, atau bentuk lainnya lewat berbagai bentuk media komunikasi, yang memuat kecabulan atau eksploitasi seksual yang melanggar norma kesusilaan dalam masyarakat (Yudhoyono, 2008). Syarat dan tata cara perizinan pembuatan, penyebarluasan, dan penggunaan produk pornografi diatur dalam peraturan perundang-undangan untuk tujuan dan kepentingan pendidikan dan kesehatan dinyatakan tetap berlaku sepanjang tidak bertentangan atau belum diganti berdasarkan peraturan pemerintah (Yudhoyono, 2014). Syarat yang harus dipenuhi dalam pembuatan, penyebarluasan, dan penggunaan produk pornografi yaitu:

a. Mempunyai sistem pengawasan.

b. Mempunyai fasilitas untuk mengamankan akses.

c. Mempunyai mekanisme untuk memverifikasi jenjang pendidikan.

d. Mempunyai mekanisme untuk memverifikasi usia.

Pemerintah pusat maupun daerah benar-benar wajib melindungi anak yang menempuh kegiatan pendidikan atau pembelajaran di sekolah dasar (Sakti, 2016b). Pemerintah harus mengawasi muatan dan konten negatif yang dicetak di buku yang digunakan pada jenjang sekolah dasar. 


\section{Pengawasan Buku Sekolah Dasar}

Sistem perbukuan telah dijelaskan dalam Undang-Undang Republik Indonesia Nomor 3 Tahun 2017 menyebutkan bahwa pembinaan dan pengawasan perlu diadakan terhadap buku pendidikan. Buku-buku yang perlu dibina, dikontrol, diawasi, dan dikembangkan ialah buku teks, non teks, dan buku umum (Yulianto, 2017).

Pustakawan Universitas Negeri Malang Profesor Joko Saryono menilai, buku-buku bacaan yang diadakan pemerintah harus memperkaya imajinasi, mempertajam akal budi, mengokohkan logika, memperhalus rasa dan memperkuat hasrat ingin tahu selain dapat menghibur (Aminudin, 2017). Penggunaan buku teks hanya berlaku jika: kreativitas guru tidak dibatasi, kebutuhan guru dipenuhi, buku teks disusun dengan realistik memperhitungkan situasi belajar mengajar di kelas, buku teks mempunyai topik yang relevan dan menarik siswa, buku teks tidak menjadikan guru sebagai budak dan pelayan, dan gaya belajar siswa diadaptasikan dengan buku teks (Jumanto \& Zuhdan, 2015).

Sistem perbukuan ialah tata pengelolaan perbukuan yang dapat dipertanggungjawabkan secara terpadu dan menyeluruh, yang mencakup pemerolehan naskah, pencetakan, penerbitan, pengembangan buku elektronik, penyediaan, pendistribusian, pengawasan, dan penggunaan buku (Widodo, 2017). Pihak sekolah dasar yang tidak memakai buku teks utama akan mendapat sanksi administratif antara lain:

a. Sekolah dasar mendapat peringatan tertulis.

b. Pemerintah akan menhentikan bantuan pendidikan.

c. Pemerintah akan mencabut status akreditasi.

d. Pemerintah akan menghentikan sementara penyelenggaraan pendidikan sekolah

e. Pemerintah akan membekukan kegiatan penyelenggaraan pendidikan sekolah

Seluruh buku yang dipakai di satuan pendidikan harus dievaluasi (Baswedan, 2016). Sanksi akan diberikan bagi penulis dan penerbit jika ada informasi yang ditulis salah mengenai pengisian formulir pernyataan informasi mengenai data judul buku, riwayat penulis, dan riwayat penerbit. Formulir tersebut telah disediakan Badan Standar Nasional Pendidikan dan Kementerian Pendidikan dan Kebudayaan (Kemendikbud). Sanksi yang diberikan Kementrian Pendidikan dan Kebudayaan adalah:

a. Buku penulis dan penerbit dilarang digunakan di sekolah.

b. Pihak Kemendikbud akan memasukkan nama penulis dan penerbit dalam daftar hitam (blacklist).

c. Pihak sekolah dilarang menggunakan seluruh buku yang ditulis oleh penulis dan penerbit dalam waktu tiga tahun.

Saran dan kritik mengenai buku pelajaran yang digunakan di sekolah tetap dibuka oleh Pusat Kurikulum dan Perbukuan Kemendikbud (Seftiawan, 2017). Masyarakat dapat menyampaikan saran berupa penilaian kriteria kelayakan buku pelajaran, buku teks, non teks, dan buku umum yang telah dicetak dan diterbitkan oleh penerbit. 


\section{SIMPULAN}

Siswa sekolah dasar yang memiliki kecerdasan linguistik secara baik akan mudah menghafal kata-kata dengan tepat dan mempunyai kosakata yang luas. Siswa sekolah dasar yang memiliki kecerdasan visual-spasial tinggi akan aktif dalam berimajinasi.

Pihak sekolah dasar harus menggunakan buku yang memenuhi nilai dan norma positif yang terdapat di masyarakat antara lain tidak mengandung unsur kekerasan, pornografi, dan tidak mengandung nilai penyimpangan lainnya. Seluruh buku yang digunakan di sekolah dasar harus dievaluasi. Penulis dan penerbit yang menuliskan informasi yang salah dalam pengisian formulir pernyataan informasi mengenai data judul buku, riwayat penulis, dan riwayat penerbit harus mendapat sanksi.

Buku pelajaran yang digunakan siswa sekolah dasar adalah salah satu informasi penting pembentuk pola pemikiran siswa. Siswa sekolah dasar akan berpikir positif atau negatif berdasarkan apa yang dilihat dari buku pelajaran. Oleh karena itu, kelayakan buku pelajaran sekolah dasar menjadi tanggung jawab dan ditentukan berbagai pihak yang terlibat dalam bidang pendidikan meskipun guru adalah komponen penting yang harus menilai kelayakan buku pelajaran.

\section{DAFTAR PUSTAKA}

Alius, S. (2017). Pedoman Umum Forum Koordinasi Pencegahan Terorisme Di Daerah (p. 34). Bogor: Badan Nasional Penanggulangan Terorisme.

Aminudin, M. (2017). DPRD Minta Buku Misteri Hantu Gentayangan Ditarik dari Sekolah. Retrieved July 3, 2018, from https://news.detik.com/berita-jawa-timur/d3673049/dprd-minta-buku-misteri-hantu-gentayangan-ditarik-dari-sekolah

Armstrong. T. (2005). Setiap Anak Cerdas. Jakarta: Gramedia Pustaka Utama.

Baswedan, A. (2016). Peraturan Menteri Pendidikan dan Kebudayaan Nomor 8 Tahun 2016 Tentang Buku Yang Digunakan Oleh Satuan Pendidikan (p. 11). Jakarta: Berita Negara Republik Indonesia.

Bomantama, R. (2018). Mendikbud: Siswa di Sekolah Akan Mempunyai 2 Jenis Rapor, Konsepnya Sedang Disiapkan dengan Balitbang .Tribunnews.com. Retrieved July 3, 2018, from http://www.tribunnews.com/pendidikan/2017/08/31/mendikbudsiswa-di-sekolah-akan-punya-2-jenis-rapor-konsepnya-sedang-disiapkan-denganbalitbang

Bona, M. F. (2016). Penulis Buku Sekolah Harus Mencantumkan Data Penulis BeritaSatu.com. Retrieved July 3, 2018, from http://www.beritasatu.com/pendidikan/374288-penulis-buku-sekolah-harusmencantumkan-data-penulis

Gardner, H. (2011). Frames of mind. New York: Basic Books. https://doi.org/10.2307/3324261

Jasmine, J. (2012). Metode Mengajar Multiple Intellengences. Bandung: Nuansa Cendekia.

Jumanto, \& Zuhdan, K. P. (2015). ANALISIS KUALITAS BSE DAN NON-BSE SAINS

SD DENGAN SISTEM PENILAIAN BUKU TEKS SAINS. JURNAL PRIMA 
EDUKASIA, 3, 133-142. Retrieved from http://journal.uny.ac.id/ index.php/ jpe/ index

Lwin, M. (2008). Cara Mengembangkan Berbagai Komponen Kecerdasan. Jakarta: PT Indeks.

Media, C. M. (2018). Anggota Komisi IV DPRD Batam Menggelar RDP dengan Disdik Batam Mengenai Teknis PPDB. Metrobatam.com. Retrieved July 3, 2018, from https://metrobatam.com/anggota-komisi-iv-dprd-batam-gelar-rdp-dengan-disdikbatam-mengenai-teknis-ppdb/

Ridha, A., Pradana, T. D., \& Mayarestya, N. P. (2017). PENGARUH MEDIA KOMIK TERHADAP PENGETAHUAN KESEHATAN MATA PADA ANAK. JURNAL VOKASI KESEHATAN, 3(2), 1-6. Retrieved from http://ejournal.poltekkespontianak.ac.id/index.php/JVK\%OAPENGARUH

Rohman. A. (2009). Memahami Pendidikan dan IImu Pendidikan. Yogyakarta: Laksbang Mediatama.

Sakti, B. P. (2016a). ETIKA DAN DAN PROFESI GURU SEKOLAH DASAR DI TENGAH PERKEMBANGAN ZAMAN. Proceeding PGSD Universitas Kuningan 2016, 1(1), 99-107. Retrieved from https://proceeding.uniku.ac.id/index.php/ pgsd2016/ article/ view/ 10

Sakti, B. P. (2016b). INDIKATOR SEKOLAH DASAR RAMAH ANAK. PROSIDING SEMINAR NASIONAL PKO FKIP UTP, 163-176. Retrieved from http://digilib.utp.ac.id/ index.php?p=show_detail\&id=2188

Sakti, B. P. (2017a). INDIKATOR PENGEMBANGAN KARAKTER SISWA SEKOLAH DASAR. MAGISTRA UNWIDHA KLATEN, 30, 1. Retrieved from http://journal.unwidha.id/ index.php/ magistra/ article/ view/ 836

Sakti, B. P. (2017b). PERSEPSI MAHASISWA PROGRAM STUDI PENDIDIKAN GURU SEKOLAH DASAR UNIVERSITAS WIDYA DHARMA TENTANG ETIKA MAHASISWA. Premiere Educandum: Jurnal Pendidikan Dasar Dan Pembelajaran, 7(02), 135. https://doi.org/ 10.25273/ pe.v7i2.1732

Sefrina. A. (2013). Deteksi Minat Bakat Anak. Yogyakarta: Media Pressindo.

Seftiawan, D. (2017). Jerusalem Jadi Tel Aviv, Kemendikbud Ralat Buku IPS SD | Pikiran Rakyat. Retrieved July 3, 2018, from http://www.pikiranrakyat.com/pendidikan/2017/12/14/jerusalem-jadi-tel-aviv-kemendikbud-ralatbuku-ips-sd-415898

Sumiati, N. (2014). OPTIMALISASI PERKEMBANGAN DAN KECERDASAN BERGANDA (MULTIPLE INTELEGENCES) ANAK SD MELALUI PERTUNJUKAN SANDIWARA BONEKA BERKARAKTER CERITA RAKYAT. JURNAL EDUHUMANIORA, 6(1), 37-47.

Suparno. P. (2004). Teori Intelegensi Ganda dan Aplikasi di Sekolah. Yogyakarta: Kanisius.

Suyadi. (2010). Psikologi Belajar PAUD. Yogyakarta: Pustaka Insan Madani.

Vinanda, R. A. (2017). Nilai Ujian Buruk, Bocah Kelas 4 Sekolah Dasar Nekat Bunuh Diri: Okezone News. Retrieved July 3, 2018, from https://news.okezone.com/read/2017/12/13/18/1829983/nilai-ujian-buruk-bocahkelas-4-sekolah-dasar-nekat-bunuh-diri

Widodo, J. (2017). Undang-Undang Republik Indonesia Nomor 3 Tahun 2017 Tentang Sistem Perbukuan (p. 31). Jakarta: Lembaran Negara Republik Indonesia. 
Yudhoyono, S. B. (2008). Undang-Undang Republik Indonesia Nomor 44 Tahun 2008 tentang Pornografi (p. 9). Jakarta: Lembaran Negara Republik Indonesia. https://doi.org/10.1017/CBO9781107415324.004

Yudhoyono, S. B. (2012). Undang-Undang Republik Indonesia Nomor 7 Tahun 2012 Tentang Penanganan Konflik Sosial (p. 45). Jakarta: Lembaran Negara Republik Indonesia.

Yudhoyono, S. B. (2014). Peraturan Pemerintah Republik Indonesia Nomor 5 Tahun 2014 Tentang Syarat Dan Tata Cara Perizinan Pembuatan, Penyebarluasan, Dan Penggunaan Produk Pornografi (pp. 1-17). Jakarta: Lembaran Negara Republik Indonesia.

Yulianto, A. (2017). Kementerian Agama Membahas Hasil Penilaian Buku Teks PAI. Republika Online. Retrieved July 3, 2018, from https://republika.co.id/berita/ pendidikan/ eduaction/ 17/10/29/ oyl4fx396-kementerian-agama-bahas-hasilpenilaian-buku-teks-pai 